\title{
Gastric Aspirate Findings in Neonatal Pneumonia
}

\author{
C. Y. YEUNG and ANITA S. Y. TAM \\ From the Paediatric ' $B$ ' Unit, Queen Elizabeth Hospital, Kowloon, Hong Kong
}

\begin{abstract}
Yeung, C. Y., and Tam, A. S. Y. (1972). Archives of Disease in Childhood, 47, 735. Gastric aspirate findings in neonatal pneumonia. A study on the gastric aspirate findings in infants with features of neonatal pneumonia and in healthy controls is presented. Definite pneumonia was associated with thickly mucoid gastric fluid containing a high proportion of polymorphonuclear leucocytes. Healthy infants had thin fluid and predominance of 'non-leucocytes' in the gastric smear. It is suggested that gastric aspirate cellularity is of diagnostic value for neonatal pneumonia. A polymorph count of over $75 \%$ indicates infection and warrants appropriate antibiotic therapy, and a count of over $35 \%$ suggests the possibility of underlying infection.
\end{abstract}

The diagnosis of infection may be difficult to confirm in the newborn infant. Chest infection, being an important cause of death in the neonatal period (Butler and Bonham, 1963), may remain so inconspicuous that the final diagnosis is often revealed only at necropsy. Other cases may present with nonspecific symptoms which mimic many non-infective neonatal conditions. On the other hand, common symptoms of pneumonia such as respiratory distress may be features of other diseases such as hyaline membrane disease, intrapulmonary haemorrhage, heart failure, mechanical obstruction of the respiratory tract, or CNS diseases. It is therefore highly desirable to search for additional simple aids to the diagnosis of pneumonia in the young infant.

Inflammation of the fetal surface of the placenta is associated with the presence of leucocytes in the gastric aspirate (Blanc, 1959). Ramos and Stern (1969) showed that the presence of leucocytes and positive bacterial culture in the gastric fluid of the newborn infants born of mothers with prolonged rupture of membranes were useful indications of subsequent development of sepsis in these infants. Apparently, such gastric aspirate findings are the result of access of infected materials of the amnion liquor to the stomach of the newborn infant.

Normally young infants are unable to expectorate and bronchial secretions are swallowed into the stomach. Short of a direct bronchial aspirate, analysis of the gastric content may indirectly reveal whether the bronchial secretion is infected or not.

Received 1 March 1972.
Such information may be particularly useful for detecting atypical cases of pneumonia in young infants. This paper reports the result of such a study.

\section{Materials and Methods}

A Cutter size -8 sterile feeding tube was introduced nasally into the stomach after more than a 4-hour fast. The gastric content was aspirated into a sterile syringe, divided, and transferred to two sterile containers. One of the specimens was sent for bacteriological culture and the other centrifuged for 15 minutes at 2000 r.p.m. The supernatant was discarded and the sediments spread thinly on glass slides for Wright's and Gram's staining. The cells were examined and counted from areas near the four corners and an area at the centre of the Wright's smear. At least 200 cells were counted in a smear. Organisms were sought for throughout the Gram's preparation.

Infants admitted to our neonatal ward with illnesses suggestive of respiratory infections were examined and classified into 3 groups according to the clinical findings, accessory investigations, and their outcome. The first group of 9 infants consisted of those who had necropsy evidence of bronchopneumonia and in whom gastric aspiration was performed within 36 hours of death. The second group of 10 was comprised of those who presented with acute respiratory difficulty, tachypnoea (respiratory rate $60 / \mathrm{min}$ ), chest crepitations, and radiological evidence of lung mottling. These features were taken as probable evidence of pneumonia. 5 of them also had associated fever, 6 had cyanosis, and 4 repeated vomiting. The third group included infants with 'possible pneumonia'. They had respiratory symptoms which might be due to pneumonia but not all the features as listed in the second group.

Twenty-four healthy non-infected infants from the 
Maternity Wing of the hospital were also studied to serve as controls. They had been normal and healthy since birth and remained so until discharge from hospital 2 to 5 days after gastric analysis.

\section{Results}

The results of the gastric aspirate findings are shown in Tables I to IV. Tables I and II list 19 infants who had either confirmed evidence of pneumonia or clinical features indicating probable pneumonia. These infants were aged between 1 and 20 days, averaging $6 \cdot 2$ days. The 24 healthy infants selected as controls (Table IV) also had a similar average age of 6 days ( 2 to 16 days).

For the purpose of this study, the cells seen in the smears were classified into two major categories of cells, namely the polymorphonuclear leucocytes, and the other cells with round or ovoid nuclei and varying amount of cytoplasm termed collectively here as 'epithelial' cells (Fig. 1 to 4 ). The leucocytes are usually devoid of cytoplasm so that only their lobular nuclei are seen in the smear (Fig. 2). No attempt was made to differentiate what exactly the 'epithelial' cells were, though the honeycombing appearance of some (Fig. 3) suggested mucosal cells of gastric origin, and elongated ciliated ones (Fig. 4) indicated their bronchial source (Schade, 1960).

\section{Discussion}

Gastric aspiration is a standard procedure for the bacteriological diagnosis of pulmonary tuberculosis in infants and small children (Hinshaw and Garland, 1963). The bronchial secretions containing the infective materials are swallowed into the stomach because of the inability of the small children to expectorate. Similarly, as shown in this study, infective bronchial fluid aspirated from the stomach

TABLE I

Gastric Aspirate Findings in 9 Infants with Pneumonia Confirmed at Necropsy

\begin{tabular}{|c|c|c|c|c|c|c|c|c|}
\hline \multirow{3}{*}{$\begin{array}{l}\text { Case } \\
\text { No. }\end{array}$} & \multirow{3}{*}{ Sex } & \multirow{3}{*}{$\begin{array}{l}\text { Age } \\
\text { (dy) }\end{array}$} & \multicolumn{5}{|c|}{ Gastric Aspirate Findings } & \multirow{3}{*}{ Remarks } \\
\hline & & & \multirow{2}{*}{ Mucus } & \multicolumn{2}{|c|}{ Cell Counts } & \multirow{2}{*}{$\begin{array}{l}\star \text { Gram } \\
\text { Smear }\end{array}$} & \multirow{2}{*}{ Culture } & \\
\hline & & & & 'Epithelial' & Polymorphs & & & \\
\hline $\begin{array}{l}1 \\
2 \\
3 \\
4 \\
5 \\
6 \\
7 \\
8 \\
9\end{array}$ & $\begin{array}{l}M \\
M \\
M \\
M \\
F \\
M \\
F \\
M \\
M\end{array}$ & $\begin{array}{r}15 \\
1 \\
3 \\
3 \\
6 \\
3 \\
2 \\
3 \\
1\end{array}$ & $\begin{array}{l}+ \\
++ \\
++ \\
++ \\
++ \\
+ \\
+ \\
+ \\
+\end{array}$ & $\begin{array}{r}25 \\
20 \\
15 \\
20 \\
12 \\
20 \\
10 \\
8 \\
20\end{array}$ & $\begin{array}{l}75 \\
80 \\
85 \\
80 \\
88 \\
80 \\
90 \\
92 \\
80\end{array}$ & $\begin{array}{l}G- \\
G- \\
G+ \\
G+ \\
G+ \\
G- \\
- \\
G- \\
G+\end{array}$ & $\begin{array}{l}\text { Pseudomonas } \\
\text { Pseudomonas } \\
\text { Negative } \\
\text { Pneumococci } \\
\text { Staph. aureus } \\
\text { Klebsiella } \\
\text { Esch. coli } \\
\text { - }\end{array}$ & $\begin{array}{l}\text { Staph. aureus septicaemia } \\
\text { Persistent truncus arteriosus in heart failure } \\
\text { Transposition great vessels in heart failure } \\
\text { Single ventricle; septicaemia; heart failure } \\
\text { Birth asphyxia }\end{array}$ \\
\hline
\end{tabular}

Note: Average cell counts: epithelial' cells $16 \cdot 7 \%(8-25 \%)$; polymorphs $83 \cdot 3 \%$ (75-92\%).

${ }^{\star} \mathrm{G}+, \mathrm{G}-$, Gram positive or negative organisms; - no organisms seen on smear.

TABLE II

Some Features of 10 Infants with Probable Neonatal Pneumonia

\begin{tabular}{|c|c|c|c|c|c|c|c|c|}
\hline \multirow{3}{*}{$\begin{array}{l}\text { Case } \\
\text { No. }\end{array}$} & \multirow{3}{*}{ Sex } & \multirow{3}{*}{$\begin{array}{l}\text { Age } \\
\text { (dy) }\end{array}$} & \multicolumn{5}{|c|}{ Gastric Aspirate Findings } & \multirow{3}{*}{ Remarks } \\
\hline & & & \multirow{2}{*}{ Mucus } & \multicolumn{2}{|c|}{ Cell Counts } & \multirow{2}{*}{$\begin{array}{l}\text { Gram } \\
\text { Smear }\end{array}$} & \multirow{2}{*}{ Culture } & \\
\hline & & & & 'Epithelial' & Polymorphs & & & \\
\hline $\begin{array}{l}10 \\
11 \\
12 \\
13 \\
14 \\
15 \\
16 \\
17 \\
18 \\
19\end{array}$ & $\begin{array}{l}\mathrm{F} \\
\mathrm{F} \\
\mathrm{M} \\
\mathrm{M} \\
\mathrm{F} \\
\mathrm{M} \\
\mathrm{M} \\
\mathrm{F} \\
\mathrm{M} \\
\mathrm{M}\end{array}$ & $\begin{array}{r}20 \\
1 \\
16 \\
2 \\
1 \\
8 \\
12 \\
6 \\
5 \\
10\end{array}$ & $\begin{array}{l}++ \\
++ \\
+ \\
+ \\
+ \\
++ \\
++ \\
+ \\
++ \\
++\end{array}$ & $\begin{array}{r}2 \\
11 \\
10 \\
35 \\
26 \\
13 \\
15 \\
35 \\
10 \\
10\end{array}$ & $\begin{array}{l}98 \\
89 \\
90 \\
65 \\
74 \\
87 \\
85 \\
65 \\
90 \\
90\end{array}$ & $\begin{array}{l}G- \\
G+ \\
G+ \\
G+ \\
G+ \\
G- \\
G- \\
G- \\
G-\end{array}$ & \begin{tabular}{l} 
Esch. coli \\
Pneumococci \\
Negative \\
Negative \\
Staph. aureus \\
Esch. coli \\
Klebsiella \\
Klebsiella \\
\multicolumn{1}{c}{-}
\end{tabular} & Klebsiella septicaemia \\
\hline
\end{tabular}

Note: Average cell counts: 'Epithelial' cells $18 \cdot 7 \%$ (2-35\%); polymorphs $81 \cdot 3 \%(65-98 \%)$. 
TABLE III

Some Features of 7 Infants with Respiratory Symptoms Simulating Pneumonia

\begin{tabular}{|c|c|c|c|c|c|c|c|c|}
\hline \multirow{3}{*}{$\begin{array}{l}\text { Case } \\
\text { No. }\end{array}$} & \multirow{3}{*}{ Sex } & \multirow{3}{*}{$\begin{array}{l}\text { Age } \\
\text { (dy) }\end{array}$} & \multirow{3}{*}{ Clinical Features } & \multicolumn{5}{|c|}{ Gastric Aspirate Content } \\
\hline & & & & \multirow{2}{*}{ Mucus } & \multicolumn{2}{|c|}{ Cell Counts } & \multirow{2}{*}{$\begin{array}{l}\text { Gram } \\
\text { Smear }\end{array}$} & \multirow{2}{*}{ Culture } \\
\hline & & & & & 'Epithelial' & Polymorphs & & \\
\hline $20^{\star}$ & $\mathbf{M}$ & 5 & $\begin{array}{l}\text { Heart failure; persistent chest crepitations } \\
3 \text { days }\end{array}$ & + & 80 & 20 & $\mathbf{G}+$ & Esch. coli \\
\hline $21^{\star}$ & $\mathbf{M}$ & 5 & $\begin{array}{l}\text { Failed to thrive; tachypnoea dy } 1 \text {; had } \\
\text { adherent placenta and ragged membranes }\end{array}$ & + & 50 & 50 & G+ & Negative \\
\hline $22^{\star}$ & $\mathrm{F}$ & 2 & $\begin{array}{l}\text { Breech delivery } 15+\mathrm{ml} \text { liquor aspirated from } \\
\text { pharynx; tachypnoea dy } 1\end{array}$ & + & 31 & 69 & & \\
\hline $23 *$ & $\begin{array}{l}\mathbf{M} \\
\mathbf{M}\end{array}$ & 2 & Immature; RDS with chest crepitations & + & 52 & 48 & G- & Negative \\
\hline $\begin{array}{l}24 t \\
25 t\end{array}$ & $\begin{array}{l}M \\
F\end{array}$ & $\begin{array}{l}2 \\
1\end{array}$ & $\begin{array}{l}\text { Transposition of great vessels in heart failure } \\
\text { Immature baby with RDS; hyaline membrane }\end{array}$ & + & 80 & 20 & Negative & Esch. coli \\
\hline & & & disease confirmed & \pm & 65 & 35 & 一 & 一 \\
\hline $20 \mathrm{~T}$ & $M$ & 2 & PM: massive pulmonary haemorrhage & + & 70 & 30 & & Negative \\
\hline
\end{tabular}

* All infants were given antibiotics and were well a week afterwards.

+ These infants died within 24 hours of gastric analysis.

Note: Average cell counts: 'epithelial' cells $62 \cdot 5 \%(31-80 \%)$; polymorphs $37 \cdot 5 \%$ (20-69\%).

TABLE IV

Gastric Aspirate Finding in 24 Noninfected Infants

\begin{tabular}{|c|c|c|c|c|c|c|}
\hline \multirow{2}{*}{$\begin{array}{l}\text { No. of } \\
\text { Cases }\end{array}$} & \multirow{2}{*}{ Clinical Features } & \multicolumn{5}{|c|}{ Gastric Fluid } \\
\hline & & Mucus & $\begin{array}{l}\text { 'Epithelioid' } \\
\text { Cells }\end{array}$ & $\begin{array}{l}\text { Polymorpho- } \\
\text { leucocytes }\end{array}$ & $\begin{array}{l}\text { Gram } \\
\text { Smeart }\end{array}$ & Culture \\
\hline $\begin{array}{r}2 \\
5 \\
1 \\
16\end{array}$ & $\begin{array}{l}5 \text { days after exchange transfusion for ABO } \\
\text { incompatibility } \\
\text { Nonspecific hyperbilirubinaemia (serum bilirubin } \\
8-12 \mathrm{mg} / 100 \mathrm{ml} \text { ) } \\
\text { Asymptomatic hypoglycaemia } \\
\text { Nil significant }\end{array}$ & $\begin{array}{l}- \\
\frac{ \pm}{ \pm}\end{array}$ & $\begin{array}{l}100 \\
65-100 \\
93 \\
62-100\end{array}$ & $\begin{array}{l}0 \\
0-35 \\
7 \\
0-38\end{array}$ & $\begin{array}{l}0 \\
3 / 5 \\
0 \\
13 / 16\end{array}$ & $\begin{array}{l}0 \\
0 \\
0 \\
4 / 16\end{array}$ \\
\hline
\end{tabular}

Note: Average age of infants: 6 days (2-16 days).

Average cell counts: 'epithelial' cells $90 \cdot 5 \%$ (62-100\%); polymorphs $9 \cdot 5 \%(0-38 \%)$.

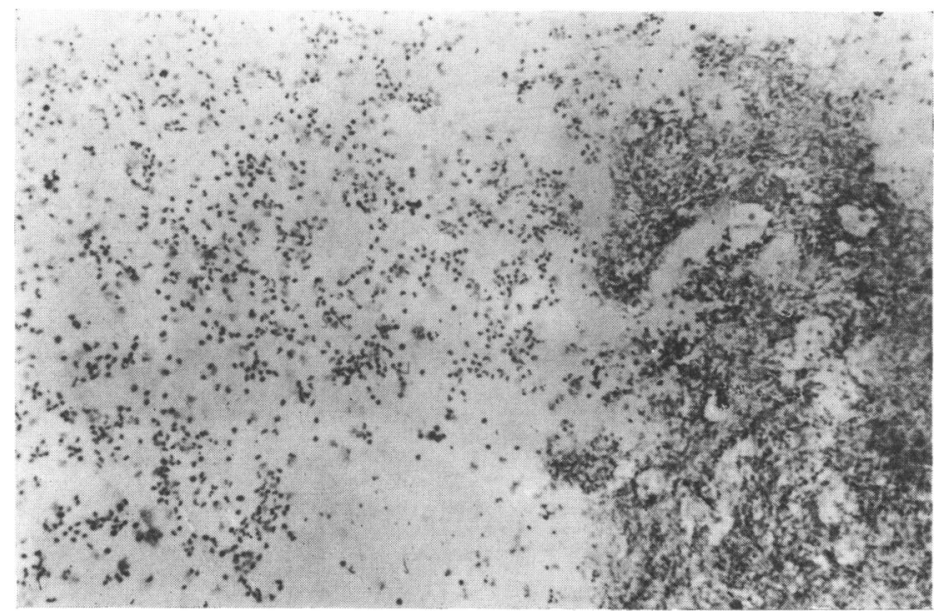

FIG. 1.-Low power view showing a patch of mucus on the right and numerous polymorphs on the left, from the gastric aspirate of an infant who died of pneumonia. ( $\times 100$. 


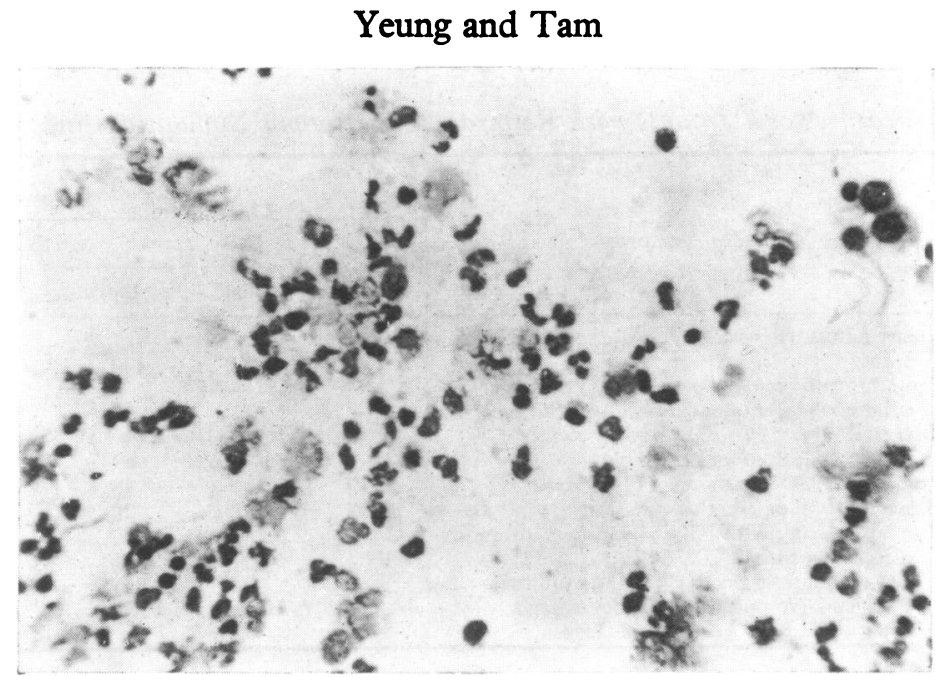

FIG. 2.-High power view showing 'naked' polymorphs from the pneumonic infant. ( $\times 450$.

of infants with pneumonia can be of diagnostic value.

In the immediate postnatal period, cells recovered from the infant may be of maternal origin. Materials ingested by the fetus on its passage through the birth canal may constitute important components of the gastric aspirate of these infants in the early hours of birth. All the infants included in this study were beyond the first day of birth. And since the normal gastric emptying time is about 3 to 4 hours in newborn infants (Davidson, 1968; Gryboski, 1965), the gastric content thus obtained in even the youngest of our infants was most probably not of maternal source.
The pus cells seen in the gastric aspirate of these infants were predominantly mature-looking polymorphonuclear leucocytes (Fig. 2) which appeared 'naked' without much cytoplasm. Though a left shift of the myeloid series in the blood was encountered in several infants, distinct early myeloid cells or band forms were rarely encountered in their gastric smears. This might be due to the differences in response of the different white blood cells to inflammatory reaction regardless of their peripheral count as pointed out by several authors (Oski and Naiman, 1966; Eitzman and Smith, 1959).

Infants who died of pneumonia (Table I)

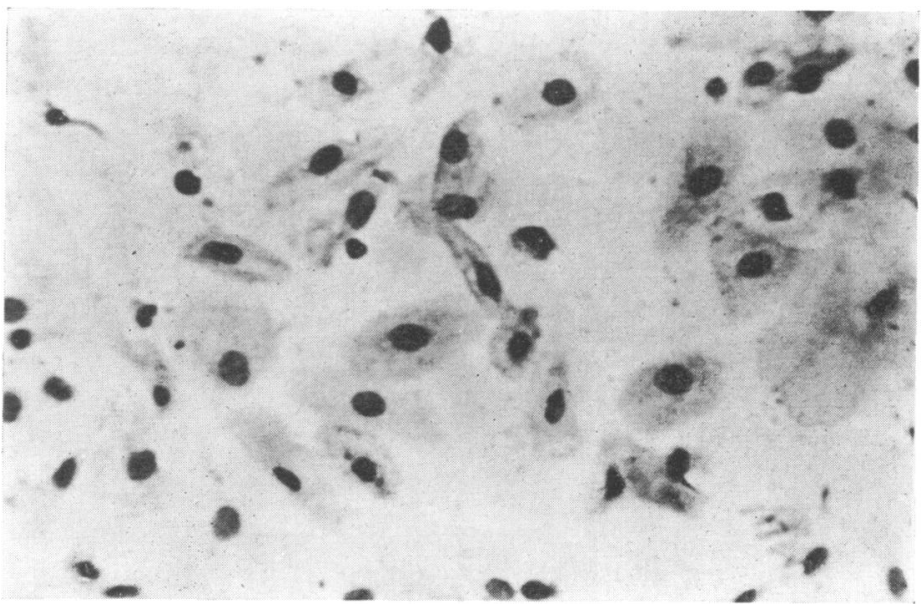

FIG. 3.-Gastric aspirate smear from a healthy infant showing cells with ovoid nucleus, abundant cytoplasm, and 'honey-combing' appearances suggestive of gastric chief cells. $(\times 450$. 


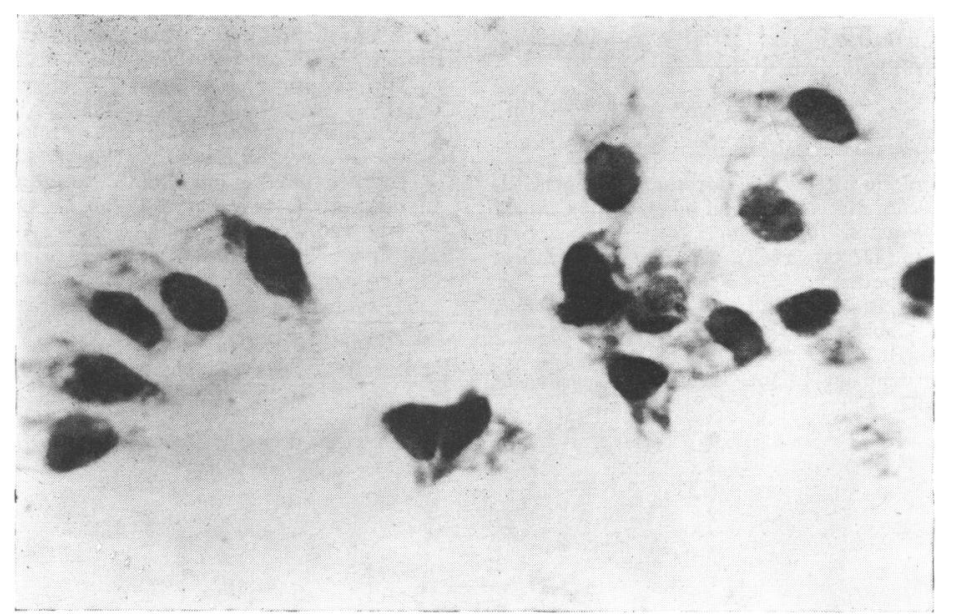

usually had thick mucus in the gastric aspirate and the smear consisted predominantly of polymorphonuclear leucocytes of over $75 \%$. In the controls (Table IV), however, the gastric fluid is usually not mucoid and over $62 \%$ of the cells seen in the smear are not polymorphs but 'epithelial' cells. Infants with clinical features of pneumonia (Table II) had gastric aspirate findings very similar to those who died of chest infection. On repeating the study 7 days after treatment, 3 of them (Cases 14, 15, and 18, Table II) showed a marked decrease of polymorphs in the gastric smear to below $20 \%$. 3 of the infants who had respiratory symptoms simulating pneumonia died (Table III). None of them showed evidence at necropsy of pneumonia and it is interesting to note that their gastric aspirate findings closely resemble those of the controls.

Ramos and Stern (1969) suggested that the presence of three or more leucocytes per high power field of the gastric aspirate in newborn infants with a history of prolonged rupture of membranes might be useful in identifying the infants at risk of developing subsequent infection. We have shown in this study that leucocytes are present in the gastric fluid of healthy infants and as high as $35 \%$ in infants (Cases 24, 25, and 26, Table III) who showed no evidence of pneumonia at necropsy. Therefore, the presence of a few leucocytes under the high power field may not be important but the occurrence of over $75 \%$ of polymorphs among the cells in the gastric aspirate supports a diagnosis of pneumonia.

We do not find bacteriological growth from gastric aspirate helpful for the diagnosis of neonatal pneumonia. Negative results were obtained in definite (Case 3, Table I) and probable (Cases 13 and 14, Table II) infections, and many positive results were yielded among the healthy controls (Table IV) and the noninfected neonatal death (Case 24, Table III). Positive bacteriology in the controls was probably the result of colonization along the pathway of the nasally introduced gastric tube and it may also reflect the degree of sterility of the environment. Heavy colonization by organisms of low pathogenicity is probably an important factor in the occurrence of leucocytes and positive bacteriological growth from our otherwise healthy non-infected infants.

Four newborn infants who died presented with congestive heart failure associated with clinical evidence of congenital heart disease. It is interesting to note that 3 of them (Cases 6,7 , and 8, Table I) with necropsy evidence of pneumonia showed a predominance of polymorphs in the gastric aspirate smear. On the contrary, the one who showed no evidence of infection had $80 \%$ of the cells being non-leucocytes (Case 24, Table III). The infant (Case 9, Table I) who apparently died of asphyxia neonatorum with $80 \%$ gastric cells being polymorphs had unexpected findings of pneumonia at death. These features suggest that in infants presenting with features of diseases other than chest infection, the presence of gastric cellularity of over $75 \%$ polymorphs should indicate underlying pneumonia and warrant institution of appropriate antibiotic therapy. Gastric aspirate cytology of over $35 \%$ polymorphs should arouse one's suspicion of pneumonia in the young infant. 
We are grateful to Dr. V. Lee for clinical assistance and the Director of Medical and Health Services of Hong Kong for permission to publish.

\section{REFERENCES}

Blanc, W. A. (1959). Amniotic infection syndrome: pathogenesis, morphology and significance in circumnatal mortality. Clinical Obstetrics and Gynecology, 2, 705.

Butler, N. R., and Bonham, D. G. (1963). Perinatal Mortality, p. 207. Livingstone, London.

Davidson, M. (1968). The Biologic Basis of Pediatric Practice, p. 814. Ed. by R. E. Cooke. McGraw-Hill, New York.

Eitzman, D. V., and Smith, R. T. (1959). The nonspecific inflammatory cycle in the neonatal infant. American fournal of Diseases of Children, 97, 326.
Gryboski, J. D. (1965). The swallowing mechanism of the neonate. I. Esophageal and gastric motility. Pediatrics, 35, 445.

Hinshaw, H. C., and Garland, L. H. (1963). Diseases of the Chest, 2nd ed., p. 30 . Saunders, Philadelphia.

Oski, F. A., and Naiman, J. L. (1966). Hematologic Problems in the Newborn, p. 229. Saunders, Philadelphia.

Ramos, A., and Stern, L. (1969). Relationship of premature rupture of the membranes to gastric fluid aspirate in the newborn. American fournal of Obstetrics and Gynecology, $105,1247$.

Schade, R. O. K. (1960). Gastric Cytology: Principles, Methods and Results, p. 135. Arnold, London.

Correspondence to Dr. C. Y. Yeung, Department of Pediatrics, McMaster University, Hamilton, Ontario, Canada. 